\title{
Shakespeare on the Screen: Brazilian cinema and TV
}

\section{Aimara da Cunha Resende}

\section{(2) OpenEdition \\ 1 Journals}

\section{Electronic version}

URL: http://journals.openedition.org/shakespeare/3574

DOI: 10.4000/shakespeare.3574

ISSN: 2271-6424

\section{Publisher}

Société Française Shakespeare

\section{Electronic reference}

Aimara da Cunha Resende, "Shakespeare on the Screen: Brazilian cinema and TV ", Actes des congrès de la Société française Shakespeare [Online], 33 | 2015, Online since 10 November 2015, connection on 02 June 2020. URL : http://journals.openedition.org/shakespeare/3574 ; DOI : https://doi.org/ 10.4000/shakespeare.3574

This text was automatically generated on 2 June 2020 .

(c) SFS 


\title{
Shakespeare on the Screen: Brazilian cinema and TV
}

\author{
Aimara da Cunha Resende
}

1 Any discussion of significant Brazilian appropriations of Shakespeare's plays must start from the realization that in them one finds not only the "crossroads of culture", ${ }^{1}$ but also the crossroads inside one's own culture, given that Brazil's vast territorial extension is populated by multicultural communities, and its geographic, economic, educational, and folkloric circumstances are extremely varied.

2 After the Manifesto Modernista (Modernist Manifesto) and the Semana de Arte Moderna (Week of Modern Art), in 1922, and imbued with the precepts found in the Manifesto Antropófago (Anthropophagic Manifesto), artists and writers throughout the country began to express nationalist values independent of, but also nurtured on, European standards. The creed was to create a Brazilian art that was nourished by the European canon, while "digesting" it and producing as a result a symbiosis of the foreign canon and national values, among them popular artistic manifestations. Canonical works of art were then to be assimilated and turned into an independent re-creation where socio-political contexts would appear in a state that would allow an awareness of Brazilianity.

3 In the wake of Roman Jakobson's theory of translation ${ }^{2}$ and his proposal of the word transmutation for what he classifies as intersemiotic translation, Eco develops his discussion of transmutation, that he also calls adaptation, that is "an interpretation of verbal signs by means of signs of non-verbal sign systems". ${ }^{3}$ Proposing the consideration of substance and matter as aspects responsible for the differentiation of sorts of translation (and here he includes intersemiotic translation), Eco adopts Jakobson's term which he also calls adaptation, and stresses the importance of matter when the change of signs occurs. Thus if one accepts his proposal, when considering the transmutation of a play into film or TV productions, choices based on matter will certainly occur and some elements from the source text must disappear while some additions may also take place in the target creation. In his discussion Eco also emphasises the fact that in any case of transmutation/adaptation there is always the 
translator's/director's critical stance defining the elements that are to be essential in the new construct: "Therefore adaptations always constitute a critical standpoint, even if an unconscious one, even if due to lack of skill rather than a deliberate interpretative choice. [...] [I]n translation the critical attitude of the translator is in fact implicit, and tends be concealed, while in adaptation it becomes preponderant and constitutes the very essence of the process of transmutation." ${ }^{4}$

I will here use the term transmutation, according to Eco, but not adaptation, as I see the latter as a more comprehensive term, of which transmutation, rephrasing, appropriation, parody are components.

Critically reading Hollywood productions, director Watson Macedo created a now anthological balcony scene as an offspring of Shakespeare's Romeo and Juliet. In his 1949 "chanchada" Carnaval no Fogo, starring two major Brazilian comedians, Oscarito and Grande Otelo, Shakespeare's two famous balcony scenes in Romeo and Juliet are conflated, ridiculing the dominant cultural elite and protesting against the prevailing presence of American films in the country. Oscarito and Grande Otelo are shown in the film rehearsing the balcony scene for a presentation to the director of the shows in the luxurious Copacabana Palace Hotel. All sorts of "transmutation", to use Umberto Eco's expression, take place in this scene by Macedo: Juliet is played by a black man while Romeo is white; words from Shakespeare's text are traversed by puns from contemporary Brazilian slang and expressions that subvert the cultural icon by directing the audience to the cultural snobbishness of the high-brow sector of society. The canon is turned into a complement to a national cultural product called the "chanchada", a Brazilian musical comedy of the nineteen-thirties and forties that generally launched Carnival songs and capitalized on the then highly appreciated "Teatro de Revista", a kind of musical in which dancing by beautiful "mulatas" (mestizo girls) was the central entertainment and well known popular singers - mostly male - launched the songs for the coming carnival. ${ }^{5}$

Shakespeare's words in both his balcony scenes are here conflated and comically distorted as when, for instance, the "transfigured" Romeo says to black Juliet: "My love, let me caress thy ivory hands, feel all the brightness of thy blue eyes, two of the fairest stars in all the heaven." Or when Juliet, afraid of the possibility of her father arriving there and finding Romeo, says to him:

JULIET. Romeu, ouço passos lá dentro. Vai, Romeu, ele quer te matar.

[Romeo, I hear steps within. Go, Romeo. He wants to kill thee.]

ROMEO. Ele quem?

[He? Who?]

JULIET. Meu pai, o senhor de Capuleto.

Se ele te vir aqui...

[My father, the Lord of the Capulets.

If he spies thee here...]

ROMEO. Vai ser um espeto!

[It'll be a spit! ${ }^{6}$

"Espeto" (literally "spit"), at the time the chanchada was made, was a slang meaning basically "a rub", or "a real problem". The spit used for slaughtering a steer is metaphorically appropriated by the popular expression, carrying the denotation of a really difficult situation. So the expression contextualizes Brazilian mores at the time while subverting canonical language, but also keeping the idea of it, since it directs the audience to the danger Romeo is in. Through such subversion the highbrow tendency to quote erudite literature is ridiculed, as it points toward Shakespeare's use of rhyme 
as the language of nobility. By rhyming "Capuleto" with "espeto", the literary expression with the validation of verse as the language of nobility is turned into trivial slang not appreciated by the supposedly cultured social group the film intends to criticize. Various lines from the source text are used in this appropriation but they always carry an ironical stance since they are represented with a tinge of low comicality and often interspersed with slang and/or quotidian expressions from Brazilian Portuguese of the time.

But this "anthropophagous" balcony scene manages to introduce the cultural icon to the lower classes through the kind of comicality such classes were used to at the same time that it maintained its canonical worth and validated the new construct in its relation to the cultural capital "Shakespeare". And this construct was so well produced in another medium - film - that it is now seen as an anthological film piece. ${ }^{7}$

Back in 1978, Maurício de Souza wrote a play: Mônica e Cebolinha no Mundo de Romeu e Julieta (Monica and Onionhead in the World of Romeo and Juliet). Souza had been successfully writing comic magazines for children for a long time and his characters, known as "Mônica's gang", were familiar everywhere in the country. After the huge success achieved with his characters, he decided to reread Shakespeare's play with Mônica's gang in the Veronese roles. Mônica (Monicapuleto, in the play) is a tomboy who carries a toy rabbit wherever she goes which she uses to strike out at whoever makes her angry or to get whatever she wants. She wishes to get married and chooses for her future husband Romeu Montéquio Cebolinha, (Souza's Cebolinha [Onionhead]), a boy who is unable to pronounce the letter " $r$ " and is forced to court the tomboy who has decided to marry him. The play ends with all the characters singing and dancing, for Mônica would not have a sad ending for her love story. Given the great success achieved by the play, Bandeirantes TV had it turned into a film to be broadcast on "Children's Day" in 1979, and it was as successful as the play. ${ }^{8}$

Romeo and Juliet has been Shakespeare's text most often appropriated by Brazilian cinema. Second to it, though not so often recreated for the screen, comes Hamlet. Despite the fact that in Brazil the famous sentence "To be or not to be" is seen and heard in various situations and at different moments, the play itself has had few such appropriations. But other good transmutations of Shakespeare's plays were also made in Brazil such as A Herança (The Legacy), directed by Ozualdo Candeias, in 1971, and $O$ Jogo da Vida e da Morte (The Game of Life and Death), directed by Mario Kuperman, in 1972.

10 A recreation of Hamlet, A Herança (The Legacy), directed and produced by Ozualdo Candeias, in 1971, takes place in a rural area in Brazil under the dominion of the "coronéis" (colonels), landowners that divide among themselves the territory surrounding their farms, dictating norms and controlling all sorts of people's activities. Violence is practically the norm in such environment where well paid killers control those exploited by the "coronéis". In Candeias's film, Shakespeare's language is stripped away and a soundtrack made with music and sounds from nature takes its place, constructing the characters' emotional state. Candeias's film is a good example of Brazilian creativity. He was the creator of what was named "cinema marginal" (marginal cinema), a forerunner of contemporary filming techniques that, due to lack of financial support, had to do without good cameras, careful light projection, etc., but that was nevertheless able to result in incredibly avant-garde productions ${ }^{9}$.

11 The site for the productions of "cinema marginal" was an area of about $250 \mathrm{~km}$ near the street called Triumph - an oracular naming? - in downtown São Paulo, where 
intellectuals, outlaws and prostitutes met in the evenings to drink, talk and... produce artistically creative films. In the nineteen-twenties and thirties, some American film companies such as Paramount and Fox, to facilitate the distribution of their films, had their representatives located in the region which attracted distributors, equipment manufactories and cinematographic headquarters. This movement turned the locale into a meeting place for Brazilian independent cinema and was labeled "Boca do Lixo" (Garbage Drop).

As Bentinho says, in Portal Brasileiro do Cinema,

The Triumph Street cinema was limited to a 250 square-metre block that had four bars: two of them were frequented by cinema professionals, and the other two by outlaws who protected them in case some unsuspecting bad guy tried to rob anyone they knew. There was mutual respect and the prostitutes were friends. ${ }^{10}$

A Herança begins with the coffin of Omeleto's (Hamlet, in the film) father being carried to its burial place (a hole dug somewhere in the arid land he had owned). Taken on a " carro de boi", a cart pulled by two oxen, the corpse is followed only by his widow, his brother, the vicarious Polonius (probably the administrator of the lands now possessed by his brother), two young women, one of them being Ophelia, and the latter's brother. By the hole dug in the earth, they stop, open the coffin, the widow draws near. She takes a crucifix she wears around her neck throughout the film - a sign of misplaced religiosity - and puts it to the dead man's lips. The coffin is closed again, and the next take is the wedding of the widow and her brother-in-law, with the newly wed leaving the small farm chapel, the bridegroom smiling and the bride with an impenetrable expression that leaves the spectator in the same sort of doubt the audience of Shakespeare's Hamlet has at watching Gertrude's behaviour throughout the source text: guilty or not guilty? The ceremony, this time, has more participants, showing that the new owner has already gathered his supporters/flatterers.

Then Omeleto arrives and realizes that his mother is already married to his uncle. Later on he will meet and make love to Ophelia, his former girlfriend. The spectator can easily follow Shakespeare's story despite the fact that the film is mostly silent. Silence, in A Herança, speaks very expressively as it gives way to music of different sorts. Most of the film's soundtrack is music played on a "viola", a popular string instrument in Brazilian rural areas. The sound heard in the film is often discordant, which succeeds in speaking to the spectator of the inner conflicts permeating the story. In the scenes between Omeleto and Ophelia, though, the music changes and one hears the melody of Sertaneja ("Country Girl"), a song from Brazilian folklore that tells of the composer's/ singer's love for a country girl who cries when she hears him singing. Another moment of intense feeling created by simultaneous visual and musical performance is when Ophelia, now mad, comes to the vicarious Claudius and Gertrude (in Candeias's film one only knows the name of the main character, Omeleto), dancing with a baby in her arms. The baby is not seen, covered up in some fabric. Ophelia leaves it in Gertrude's arms and a lullaby is heard, the lyrics of which go: "sleep, baby, for it is now time to sleep...". But one hears only the melody, no words.

Leaving the baby in Gertrude's arms, Ophelia turns away. Gertrude and Claudius are shocked - as we, the spectators, are - when Gertrude uncovers the baby and only three branches from a banana tree are seen, with thin fruit and pointed ends, called "hearts" in Portuguese. Candeias thus gets to one of his most creative and erotic moments of symbolic - but silent - language, expressing what Shakespeare has done by means of the famous erotic symbolism of the flowers in Ophelia's mad speech. The country girl, 
now mad perhaps owing to the conflicting feelings of having a father killed by the man she loves and the understanding that she is lost for the world she lives in because she has yielded to Omeleto's sexual demands, silently expresses all the anguish her model has been able to show through spoken language. She keeps on dancing and behaving like a little girl. Whenever there are love encounters between her and Omeleto, Candeias introduces takes of wildflowers suggestive of those Ophelia distributes to the courtiers in Hamlet, act 4, scene 5.

In an article published in the online journal Contracampo, Juliana Fausto says:

The most intensely marked element in the film is perhaps the fact that it is silent. That is, it has no human speech. Speech appears as subtitles (not inter-titles, as in silent cinema, but real subtitles) while we may hear every sound in nature as it appears - and how rich it is on a farm, with birds, the wind, and everything else that makes up such a place. One may say that in this sense the film is constructed on three levels: we read Shakespeare, we hear the sounds of the farm - Brazil - and we see the result of the interchange between the two. ${ }^{11}$

But Candeias chooses to use spoken or sung language twice: when Omeleto, an ox skull in his hand, speaks the famous first lines of Hamlet's soliloquy: "To be or not to be... That is the -" and he stops here. The situation is ironic, not metaphysical, as it is in Shakespeare's text, for he laughs at the skull as he says the words and then moves away, walking by a pond followed by Ophelia who seems to be taking a letter - probably written by him to her which she is to return to him. He stops three times and so does she, before he comes close to her, apparently intending to hug her, but she kneels down and he leaves her, still carrying the skull in his hand. The second time one hears something is the mousetrap scene, now turned into a country type song the lyrics of which narrate the story of the murder of a landowner by his brother, who then marries the widow. Sung by a circus singer, the song Omeleto has arranged works to confirm his suspicion, just as it happens in Shakespeare, through the play-within-the-play.

Shakespeare's words in Hamlet are often quoted, like, for instance, parts of the "Hecuba" (2.2.560-607) and the "How all occasions do inform against me" monologues, ${ }^{12}$ and the words spoken by Marcellus: "Something is rotten in the state of Denmark" (1.4.67) are turned into a saying belonging to the rural environment, when Omeleto's companion says (he is not heard, the words are only seen on the subtitle), after they see and hear the ghost: "Tem algo podre no fazendão" (There's something rotten on the big farm). The big farm, an ancient rural mansion, was the dwelling place of the dead " coronel" and his family, and is now empty and haunted by the ghost of its previous owner, Omeleto's father.

At the end, after all the main characters are dead, a man arrives with a group of armed companions. He may be another "coronel" or a police agent. He checks the dead and finds Omeleto still alive when someone gives him a letter in which the young man has left his legacy: he wishes his lands to be given to those "who have always lived and worked there" - the peasants. Omeleto dies, and the man crumples the letter and throws it away, an indication that the story will probably be repeated with another violent, domineering owner taking over.

The film comes to its conclusion in a sort of circular construction, with Omeleto's dead body being carried by the peasants he loved, on a cart pulled by oxen, while one reads the subtitle: "and the rest is silence...". ${ }^{13}$ 
Danish Court is transmuted into an area "belonging" to a major drug dealer. The names of Shakespeare's characters are maintained, in Kuperman's film, except for Hamlet, who becomes João (played by Walter Cruz). Horácio/Horatio is an adolescent, younger than João, but his close friend - who does not have the maturity and education of Shakespeare's character, but embodies the usual relationships emerging in places like the one the film portrays. Marcelo (Shakespeare's Marcellus), takes on a stronger role as he has some speeches given to Horatio in the source text. The atmosphere created is stifling: smoke coming from an area that has just been burned down is often visually part of the environment, being sometimes substituted by clouds when the scenes are shot in the open air. There is dirt everywhere including an open space covered with filth where troubled João/Hamlet goes after having had the revelation of his father's murder from a "medium". In the dirty open space, he sees a female cat lying down surrounded by mice, and, taking a stick from the ground, he chases the small animals away while the cat moves out of his reach. He then moves the stick along the ground and the words from Hamlet appear on a torn piece of paper: "To be or not to be"... The visual imagery is stunning as one realizes the misery of human condition and the absurdity found in human power. Shakespeare's words are literally transposed to the atmosphere of a Brazilian underground and as the monologue moves on, João stops and draws in the dirt the diagram of the tic-tac-toe game and starts inserting crosses and circles in it as he muses on what to do. As the monologue approaches its conclusion, he throws the stick away and leaves the place.

Both the "closet" and mad Ophelia's scenes are also almost literally transposed to Kuperman's appropriation. The madness scene is worth mentioning. As Ofélia comes out of her house, already distracted, and after having had a drug injection, she stops under a drain-pipe on the roof from which water drops incessantly and rhythmically. She looks happy as she slowly gets wet, and starts speaking the lyrics of one of Ophelia's songs:

He is dead and gone, lady,

He is dead and gone,

At his head a grass-green turf

At his heels a stone.

Hamlet, 4.5.29-32

Laertes and Claudio (the latter played by the very well-known actor Juca de Oliveira) come and watch her, but Gertrudes (Odete Lara) is not present. Ofélia gives them both imaginary flowers, explaining what they are good for. Visual expression here substitutes for the songs and lines sung/spoken by Shakespeare's heroine, provoking a similar reaction in the spectators to that created by words in the play.

Claudio is the boss who has murdered his brother, taken on his power and married his widow. In this reconstruction, one notices the strength of Gertrudes's attraction to Claudio, but she also seems to feel lost in relation to all that has happened and has links to her son. Claudio is permanently drunk - he is often seen drinking "cachaça" (the main distilled drink in Brazil). In the mousetrap scene, he has drunk so much during the performance that, when he realizes that João has planned to catch him, he vomits in front of everybody. The mousetrap is performed, in Kuperman's film, by singers and 
dancers from a Samba School - another characteristic trait of Brazilian popular expression, related to carnival. The words João inserts in the plot become part of the lyrics of the samba they sing.

Another typical element taken from Brazilian social structures, now related to religious syncretism, which is superbly inserted in the appropriation, is the mãe de santo, a female medium, used by João's dead father to come and talk to him about his murder. As trances with both male and female mediums are common in the country, especially among less educated people, this choice was a tour de force.

ofélia is a highly sexualized girl. Soon after João is told by "his father" of the murder, she forces him to make love to her in the same open space where he had seen the cat and mice and the written words of the "to be or not to be" monologue. His father's death had been officially given as due to a snake bite, so when Ophelia forces him to have sex with her, he looks at her and simultaneously sees her face and a snake, at which point he slaps her and leaves. Feeling hopeless, the girl runs back to her room where she takes a cigarette and starts smoking a drug. When, forced by Polônio, she gives back to João a necklace he had given her, and he abruptly throws it away saying he had given her nothing, she looks lost. This feeling is intensified soon after when he tells her to go to a nunnery, quickly to change his mind and say that she had better go to a brothel (here the double meaning found in the word "nunnery" in Shakespeare's text is clearly transposed through the two utterly different situations João suggests she might choose to experience).

At the very end, João, struck by Laertes's knife, seeing his mother dead after having drunk the poisoned cachaça Claudio had prepared for him, still has the strength to kill Claudio, leave the dead bodies and stagger towards the same empty open space where the "to be or not to be" monologue was heard. There, he falls and dies, while, silent, Horácio looks at him. The camera focuses on Horácio who slowly vanishes. In his place one sees the silhouette of a vulture and the film ends with a shot of the big city beyond the dirty mountain of the slum - a cold, silent city, rigid with its skyscrapers, and unaware of all that has happened.

o Jogo da Vida e da Morte is a strong rereading of Shakespeare in which hybridism is taken to its maximum, and the problem of social structures in Brazil is both clear and upsetting, with the suggestion of there being no way out for the poor, who are dominated on all levels.

Little by little, Shakespeare's plays were incorporated into weekly TV broadcasts, but they were basically stage performances transposed to the small screen, not yet transmuting cultures. Shakespeare was slowly being introduced into Brazilian homes, especially in the TV novelas. The telenovela, or novela, as it is usually named by the spectators, differs from the American soap opera, as it has its own defined structure. While the soap opera is formed of intertwined stories that last "ad-infinitum", the telenovela has one main story as its backbone, with various sub-plots and will usually last for less than one year. Besides that, telenovelas do not have one or two main stars but may air a cast composed of a group of famous actors and actresses acting together with around twenty other performers not so well known. The episodes in the telenovela, differently from the soap opera that is shot much in advance, are shot about two weeks, or even less, before they are aired; this allows the plot to be changed according to eventual events that may take place during its presentation. And telenovelas usually have a happy end, which approximates them to comedy. 

(Stone over Stone), 1992, and Fera Ferida (Wounded Beast), 1993-1994. These appropriations
evoked once more the socio-political atmosphere of clans in rural Brazilian areas. The (Stone over Stone), 1992, and Fera Ferida (Wounded Beast), 1993-1994. These appropriations
evoked once more the socio-political atmosphere of clans in rural Brazilian areas. The former duplicated Shakespeare's story, as Marina/Juliet, and Leonardo/Romeo live the same experience her mother and his father had. The older couple had been unable to succeed in their love, while their children end up happily married. After all, this is a novela and can admit no tragedy. As a result of the transmutation process, it is the mass medium transmitting it that defines the structure for the new construct. ${ }^{15}$

I say Shakespeare was being introduced because, unlike what happens in Englishspeaking and perhaps some European countries, he is not familiar to the average citizen. The people who watched these TV serials when they began, belonged to the lower socio-economic stratum and watched TV at the end of the working day to relax, with little concern for more "erudite" productions.

Shakespeare has become a "global" citizen. In Brazilian terms, the word "global" conflates two meanings: the idea of belonging to the world/globe and simultaneously to the Globo Television Network. To speak of Globo TV is characteristically to speak of the novelas, its main productions. Globo TV is an active participant in the era of capital and as such distributes images of Brazil throughout the country and across the world. Responding to the demands of a society that creates and recreates its own desires, beliefs and myths, and of a global market already filled with an imaginary imbued with stereotypes, its messages attempt to satisfy some expectations while giving birth to others.

and wider representations, from inspiration to parody or the suggestion of certain scenes, and finally, in 1980, to the whole story of the Verona lovers in an appropriation of Romeo and Juliet, in Globo TV's "Caso Especial". This Romeu e Julieta was directed by Paulo Afonso Grisolli and adapted by Walter George Durst. Created under the dictatorship, it dared to allude to the system with the representation of its allies, the police and Catholic Church. In Grisolli and Durst's portraits, the more educated spectators would have recognized the criticism of the system while the less educated would have been mainly interested in the love story. Having Ouro Preto, an important eighteenth-century Baroque town in Minas Gerais, as its setting, it creates the conditions for an anthropophagic Brazilian construct. As the film begins, one hears the chimes of the innumerable churches in town and sees the rival repúblicas (students' boarding houses) where Romeu and Caveira, Paris' vicarious representation, live. The socio-political feudal enmity found in the source text is now transmuted into socioeconomical rivalry, in the behaviour of the students. Some students, like Caveira/Paris, study at the renowned Mining \& Engineering School, while others, like Romeu, at the less important Pharmacy School. With some speeches taken from the source text, this Brazilian TV appropriation keeps the main traits of its source but imbues them with national characteristics. ${ }^{14}$

Shakespeare's Romeo and Juliet is still found in two novelas of Globo TV, Pedra Sobre Pedra (Stone over Stone), 1992, and Fera Ferida (Wounded Beast), 1993-1994. These appropiations Fera Ferida appropriated both Romeo and Juliet and Hamlet, this time clearly admitting its debt to one of the source texts, in scenes such as the one that reconstructs a small portion of Shakespeare's lines spoken by Juliet about the unimportance of a name. Or when, at the funeral of the town commander in chief's son, the town teacher says Horatio's words to dead Hamlet, in act 5, scene 2: "Now cracks a noble heart. Good 
night, sweet prince, / And flights of angels sing thee to thy rest" (5.2.311-312) ${ }^{16}$. But again the plot is adjusted to Brazilian cultural values. ${ }^{17}$

In 2000, Globo TV produced O Cravo e a Rosa, a novela directed by Amora Mautner and adapted by Walcyr Carrasco. Shakespeare is never mentioned, but it creates, nevertheless, several opportunities for consideration of the meaning of love and matrimony, family relations, political maneuvers, social-economic interests and futility, just as the Bard has done. In Mautner's appropriation, Katherina, or Kate, becomes Catarina, Petruchio has "Julião" added to his original name, and becomes Julião Petruchio. Bianca is kept as Bianca and their father, called Nicanor Batista, is a very wealthy but stingy banker who hopes to be elected mayor.

The relationship between Catarina and her sister Bianca is a kind of mother-daughter's love. Catarina is a tempestuous, sharp-tongued feminist who fears nobody but loves her sister. It is this love that will give her the chance to accept Julião Petruchio's marriage proposal, which she wants to accept, having fallen in love with him, though she does not confess it to anybody. Brazilian Bianca is, from beginning to end, the prototypical sweet romantic girl.

As $O$ Cravo e a Rosa is a telenovela, it must have subplots other than the Bianca-Lucentio one, and these appear in four groups: one is a family composed of the mother, a daughter, a son and a son-in-law. The first three are typical hangers-on and the son-inlaw is a rich man who dotes on his flighty wife. The second plot is formed by Joaquim de Almeida Leal, a roguish moneybags who hates Petruchio, and his daughter Marcela, who has just arrived from Paris and seems to be in love with the young farmer. The third plot is constructed around the people working and living on Petruchio's farm.

The fourth subplot is woven around the simultaneous seduction of two young feminists, Catarina's friends, by a student who has made a bet with his companions that he will make love to the apparently more difficult of the two, and ends up with both of them and the three "living happily ever after". Petruchio's bet, in the source text, is then transposed to the student's in Globo TV's appropriation. The resolution of this relationship shows how paradoxical the use of time may become in such a production. Acceptance of relationships of this sort would be unthinkable in the nineteen-twenties, when the events of the novela supposedly took place - an epoch shown in the elaborate cinematic set, including costumes, scenery and leisure activities. But this is a text written and produced at the beginning of the twenty-first century and aimed at an audience already open-minded enough to watch it on the screen and relish the dénouement. The impermanence of TV forces such juxtaposition of time, and the borders of present and past are blurred so as to propitiate the required - and demanding - compromise between characters and audience, fiction and reality, screen and everyday life.

Aiming at audiences both at home and abroad, O Cravo e a Rosa is a product of twentieth century economy. Market capability ${ }^{18}$ begins with its appropriation of the cultural value of Shakespeare. This appropriation will give the telenovela artistic status and simultaneously provide it with a passport to foreign countries as a product of quality. Such recognition is important for sales on a large scale. At home, it may also have the recognition in the intellectual and artistic milieu while catering to simpler minds - the majority of spectators, who have not read Shakespeare but will relish the comedy in the text. 

major characters. Like its source, o Cravo e a Rosa has exhilarating moments of gender disputes. Following Shakespeare's characters, Julião Petruchio and Catarina use verbal as well as physical attacks aiming to show their individual supremacy. But as it is a telenovela, it is able to employ another device, the visual recurring presentation of some of their most intense emotional interchanges. This is, for instance, the case of a sudden kiss that Julião Petruchio gives Catarina. This kiss is seen on the screen whenever, when alone, either of them thinks of the other. The wedding scene follows its source very closely in the farcical appearance of the bridegroom that almost drives Catarina mad. And their first meeting is another exhilarating creation. After having settled with Batista the conditions to marry Catarina, Petruchio goes to her house to meet her for the first time. Batista receives him very well and calls his daughter who takes a long time to appear. When she finally arrives, the camera slowly moves along the stupefied faces of those in the living-room as they follow her coming down the stairs. We see their expression of astonishment but not the bride to be. As Petruchio looks up he is also astonished but quickly changes his surprise to a light smile and we finally see her. she comes down the stairs showing a very advanced stage of pregnancy. The prospective husband addresses her admiringly, saying that she is so beautiful that she looks like an angel and, approaching her, suddenly takes her hands in such a way that he causes the watermelon she had tied to her belly to fall on the ground. She reacts nervously while he asks her how she guessed he especially likes that fruit. And tells her father that he is very happy at observing, from her behaviour, that she wishes to get married and have a lot of children. He continues in this way during all her attempts at destroying his intelligent self-control, attempts that range from verbal attacks to throwing things at him, to which he always finds an amusing way to react.

This Brazilian Shrew presents the usual terminus both of comedy and telenovelas - the happy ending - when Catarina and Petruchio, having now been married for some time and living happy together, end up in peace on the rehabilitated and modernized farm. The telenovela ends in an idyllic countryside, the hero and heroine exchanging a long kiss and their - twin! - children throwing hearts at each other from their prams. These hearts fly in the air and finally form two joint cameos. This is a visual summary of the verbal "and they lived happily ever after", as each chapter throughout 0 Cravo e a Rosa has been introduced by various cameos, the last to appear in every chapter being two separate ones containing the pictures of Catarina and Petruchio. The union of these two cameos at the end in a joint set of two pictures visually connotes the marriage commitment and true love of the couple, suggesting through a television device Kate's final speech in the source text, but free of its ambiguity. The ambiguous end in Shakespeare's text, made possible through the use of the play within the play technique, is converted in the Brazilian appropriation into a direct avowal of emotional and intellectual communion, as it should be in a telenovela. ${ }^{19}$ 


\section{NOTES}

1. Patrice Pavis, O Teatro no Cruzamento de Culturas, trans. Nancy Fernandes, São Paulo, Perspectiva, 2008 (Le théâtre au croisement des cultures, Paris, José Corti, 1990).

2. Roman Jakobson, "Linguistic Aspects on Translation", ed. Reuben A. Brower, On Translation, Cambridge, Harvard University Press, 1959, p. 232-239.

3. Umberto Eco, Experiences in Translation, trans. Alastair McEwen, Toronto Italian Studies, Goggio Publication Series, Toronto, University of Toronto Press, 2008, p. 67.

4. Ibid., p. 126.

5. On "chanchadas," see Domingos Demasi, Chanchadas e Dramalhões, Rio de Janeiro, Funarte, 2001; and Sérgio Augusto, Este Mundo É Um Pandeiro: a chanchada de Getúlio a JK, São Paulo, Companhia das Letras, 2001.

6. Cf. William Shakespeare, Romeo and Juliet, 2.1.105-112: "The orchard walls are high and hard to climb, / And the place death, considering who thou art, / If any of my kinsmen find thee here. [...] If they do see thee, they'll murder thee" (in The Complete Works, eds. Stanley Wells and Gary Taylor, Oxford, Clarendon Press, 1986).

7. See Balcony scene of Romeo and Juliet with Oscarito and Grande Otelo, dir. Watson Macedo, 1949: https://www.youtube.com/watch?v=e-lpZdGTTGI (last accessed September 17, 2015).

8. See Mônica e Cebolinha no Mundo de Romeu e Julieta (parts), dir. Maurício de Souza, 1979: https:// www.youtube.com/watch?v=uVCSSxjx1kQ (last accessed September 17, 2015).

9. The name "marginal" comes from Ozualdo Candeias's film A Margem (The Margin), 1967, that dealt with the predicament of young women from the rural northeast who dreamt of "the big city", and their striving to survive and find deliverance from prostitution, a situation they were inevitably led to. Besides the film, the name sprang from the fact that "cinema marginal" focused on people from the lowest social class: the unemployed, prostitutes, those destitute of any hope, exploited and marginalized.

10. Bentinho, “A Boca do Lixo", Portal Brasileiro de Cinema, www.portalbrasileirodecinema.com.br/ candeias/filmes/04_02.php (last accessed September 17, 2015). My translation into English.

11. Juliana Fausto, “A Herança”, Contracampo 25, www.contracampo.com.br/25/artigos.htm (last accessed September 17, 2015). My translation into English.

12. This monologue is not found in F1, used as source for the OUP Complete Works. See the conflated edition of Hamlet in The Riverside Shakespeare, ed. G. Blakemore Evans, Boston, Houghton Mifflin, 1974, 4.4.32-66.

13. See A Herança, dir. Ozualdo Candeias, 1971 (trailer): http://www.cineweb.com.br/filmes/ filme.php?id_filme=4524 (last accessed September 17, 2015).

14. See Romeu e Julieta, Globo TV, dir. Paulo Afonso Grisolli, 1980: https://www.youtube.com/ watch?v=OsfW-pIScg4 (last accessed September 17, 2015).

15. See Pedra Sobre Pedra, Globo TV, dir. Paulo Ubiratan, Gonzaga Blota and Luiz Fernando Carvalho, 1992: https://www.youtube.com/watch?v=oYKaz61SEwE (last accessed September 17, 2015).

16. Hamlet in William Shakespeare, The Complete Works, ed. Stanley Wells and Gary Taylor, Oxford, Oxford University Press, 1986, 5.2.311-312.

17. See Fera Ferida, Globo TV, dir. Aguinaldo Silva, Ana Maria Moretzsohn and Ricardo Linhares, artistic dir. Paulo Ubiratan, 1993, 27 DVDs: https://www.youtube.com/watch?v=yjzZmxtgxhs (last accessed September 17, 2015).

18. See Michael Bristol, Big-time Shakespeare, London \& New York, Routledge, 1996.

19. See O Cravo e a Rosa, Globo TV, dir. Aurora Mautner, 2000/2001: http://globotv.globo.com/ rede-globo/o-cravo-e-a-rosa/ (last accessed September 17, 2015). 


\section{ABSTRACTS}

This article will discuss some of the outstanding Brazilian appropriations of Shakespeare for the screen (both TV and film), focusing on three productions: two films that appropriate Hamlet, the 1971 "marginal film" A Herança, and the 1972 film, O Jogo da Vida e da Morte, a "slum Hamlet", as well as O Cravo e a Rosa, a 2000/2001 TV novela inspired by The Taming of the Shrew. As Romeo and Juliet has been the play most often adapted to the Brazilian screen, I will briefly discuss five such appropriations: three films and two TV novelas, or telenovelas. Elements of popular Brazilian culture will be highlighted, showing how a bridge between the canonical foreign text and the contemporary Brazilian reality is created, allowing a general audience unused to going to the theatre to have access to the erudite cultural product. Based on Umberto Eco's notions of translation and transmutation/adaptation, the discussion will attempt to show how not only the target culture but also matter proper to the new medium determine changes in the transmuted construct.

Cet article étudie trois exemples saillants d'appropriation de Shakespeare à l'écran (télévision et cinéma) au Brésil : deux réappropriations filmiques d'Hamlet - le film «marginal » A Herança (1971) et un "Hamlet des favelas" de 1972, O Jogo da Vida e da Morte - ainsi qu'une telenovela inspirée de La Mégère apprivoisée, O Cravo e a Rosa (2000-2001). Étant donné l'importance de Roméo et Juliette au sein des adaptations brésiliennes de Shakespeare, quelques exemples liés à cette pièce seront également abordés (deux films et trois telenovelas). La présence d'éléments de la culture populaire brésilienne est importante dans le processus d'adaptation, car elle permet de mettre en rapport un texte canonique en langue étrangère et la réalité brésilienne contemporaine, donnant ainsi accès à un produit culturel érudit à toute une frange de la population qui n'a pas l'habitude d'aller au théâtre. À partir des notions de traduction et de transmutation théorisées par Umberto Eco, il s'agira de montrer que la culture cible, mais aussi le contenu propre au nouveau média, influent sur le résultat de la transmutation.

\section{INDEX}

Mots-clés: appropriation, chanchada, culture populaire, Hamlet, Manifeste Anthropophage, Mégère apprivoisée (La), Roméo et Juliette, Shakespeare et le cinéma, Shakespeare et la télévision, telenovelas brésiliennes

Keywords: Anthropophagic Manifesto, appropriation, Brazilian telenovelas, chanchada, Hamlet, popular culture, Romeo and Juliet, Shakespeare and film, Shakespeare and TV, Taming of the Shrew (The)

\section{AUTHOR}

\section{AIMARA DA CUNHA RESENDE}

Universidade Federal de Minas Gerais / Centro de Estudos Shakespeareanos 